\title{
An assessment of the regional distribution of the oxygen- isotope ratio in northeastern Canada
}

\author{
Mario B. Giovinetto, ${ }^{1}$ Gerald Holdsworth, ${ }^{2}$ David A. Fisher, ${ }^{3}$ Nigel M. Waters, ${ }^{4}$ H. Jay Zwally ${ }^{5}$ \\ ${ }^{1}$ Earth Sciences 356, University of Calgary, Calgary, Alberta T2N1N4, Canada \\ ${ }^{2}$ Arctic Institule of North America, ML T 11th floor, Calgary, Alberta T2.N1 N4, Canada \\ ${ }^{3}$ Terrain Sciences Division, Geological Survey of Canada, 601 Booth Street, Ottawa, Ontario K1A OE8, Canada \\ ${ }^{4}$ Department of Geography, University of Calgary, Calgary, Alberta T2.N 1.N4, Canada \\ ${ }^{5}$ Code 971, NASA/Goddard Space Flight Center, Greenbelt, MD20771, U.S.A.
}

\begin{abstract}
A compilation of mean values of the oxygen-isotope ratio relative to standard mean ocean water $\left(\delta^{18} \mathrm{O}\right.$, in \%o) for 22 sites representative of conditions in northeastern Canada is complemented with data on mean annual surface temperature, latitude, surface elevation, and mean annual shortest distance to open ocean denoted by the $10 \%$ sea-ice concentration boundary. Stepwise regression analysis is used to develop a multivariate model suitable to infer the distribution of $\delta^{18} \mathrm{O}$ in an area of complex topography and possibly mixed sourcing of advected water vapor. The best model is produced by a run in the backward mode at the $95 \%$ confidence level in which only temperature, latitude and distance to the open ocean remain in the model (the correlation coefficient is 0.915 , the adjusted coefficient of determination is 0.809 , the root mean square residual is 1.62). This model is similar to the best $\delta^{18} \mathrm{O}$ predictive model derived elsewhere for Greenland, suggesting a common principal source of advected moisture.
\end{abstract}

\section{INTRODUCTION}

Earlier studies of the areal distribution of ${ }^{18} \mathrm{O} /{ }^{16} \mathrm{O}$ values relative to standard mean ocean water (SMOW) $\left(\delta^{18} \mathrm{O}\right.$ in \%o) in northeastern Canada and northwest Greenland (e.g. Koerner, 1979) have focused on bivariate relationships between $\delta^{18} \mathrm{O}$ and independent variables such as mean annual surface temperature, surface elevation, and distance to the coastline. In this study we assess the areal distribution of $\delta^{18} \mathrm{O}$ and covariation of the independent variables using stepwise regression analysis.

Our compilation of $\delta^{18} \mathrm{O}$ values determined from firn samples collected in ice caps and snow fields in northeastern Canada lists 23 sites (Fig. 1 and Table 1; site 1 on the North Ice Cap, Greenland, is included because it shares the same lower troposphere flow with at least nine other sites to the west). Data for one other site on the Devon Ice Cap (at about $115 \mathrm{~km}$ on the traverse route, $75.60^{\circ} \mathrm{N}, 83.3^{\circ} \mathrm{W}, 500 \mathrm{~m}$ (Koerner and Russell, 1979)), and from two other ice caps (Meighen Ice Cap, $79.95^{\circ} \mathrm{N}, 99.4^{\circ} \mathrm{W}, 270 \mathrm{~m}$ (Koerner and Paterson, 1974); Barnes Ice Cap (five sites centered at about $69.75^{\circ} \mathrm{N}, 72.0^{\circ} \mathrm{W}$ at elevations between 500 and $870 \mathrm{~m}$ (Hooke and Clausen, 1982)) were excluded from the compilation because the samples were collected from areas either of net ablation, or of intense summer melt and percolation. On some of the ice caps, ice shelves, and snow fields listed in Table $\mathrm{l}$ there are many more sites for which $\delta^{18} \mathrm{O}$ values have been determined. We selected relatively few sites from each in an attempt to attain a regionally representative (unbiased) database.

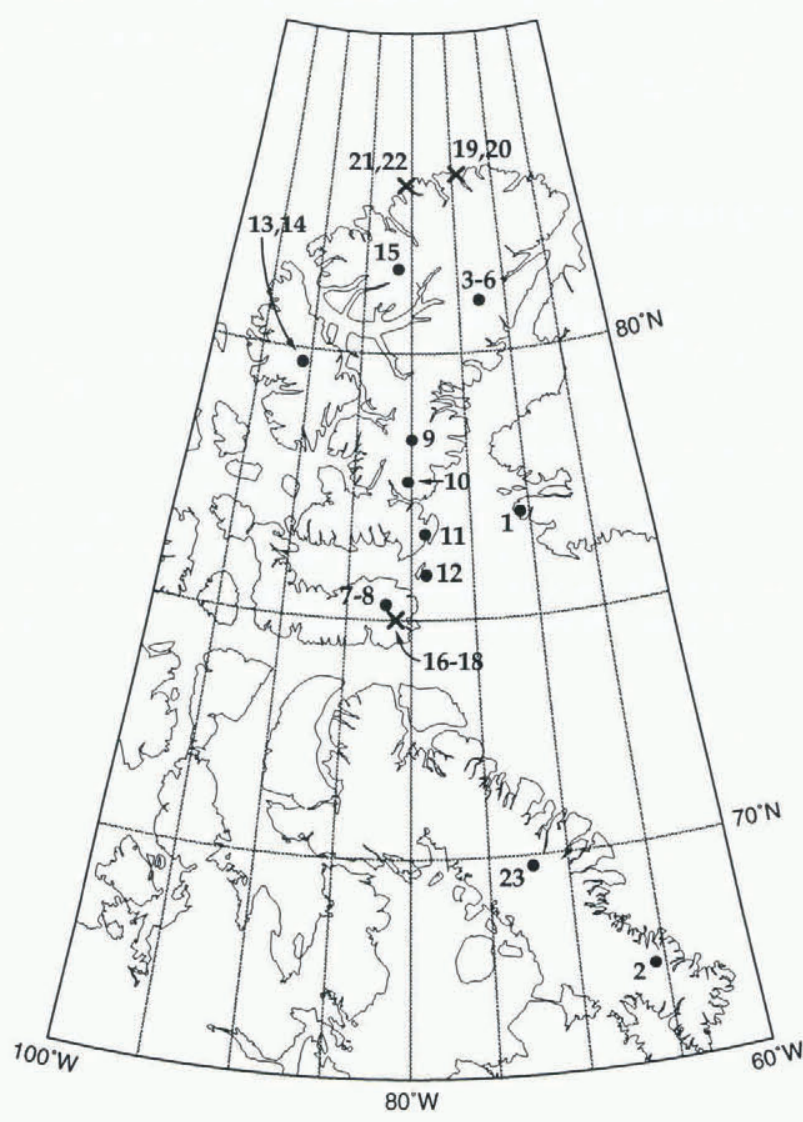

Fig. 1. Location of sites listed in Table 1. Full circles indicate sites for which mean annual surface temperature could be determined from surface data $\left(T_{\mathrm{s}}\right)$. Crosses indicate sites for which mean annual surface temperature was determined exclusively from remotely sensed data $\left(T_{\mathrm{r}}\right)$. 


\begin{tabular}{|c|c|c|c|c|c|c|c|c|c|c|c|c|}
\hline Site & Source* & Location & $L$ & Long. & $H$ & $\delta^{18} \mathrm{O}$ & $T_{\mathrm{s}}$ & $T_{\mathrm{r}}$ & $T_{\mathrm{c}}$ & $T_{\mathrm{a}}$ & $D$ & $\left(\delta^{15} \mathrm{O}\right)_{i}$ \\
\hline No. & & & $\mathrm{N}$ & W & $\mathrm{m}$ & $\%$ & $\mathrm{~K}$ & K & $\mathrm{K}$ & K & $\mathrm{km}$ & $\%$ \\
\hline 1 & 1,2 & Site V (North Ice Cap) & 77.07 & 70.4 & 1100 & -21.40 & 261.0 & 263.4 & 261.0 & 262.2 & 1440 & -20.25 \\
\hline 2 & 3 & Penny Ice Cap & 67.24 & 65.7 & 1940 & -24.60 & 258.8 & 255.2 & 258.8 & 257.0 & 480 & -24.85 \\
\hline 3 & 4 & Agassiz Ice Cap 1977 & 80.83 & 72.8 & 1670 & -30.40 & 248.6 & 251.1 & 248.6 & 249.9 & 1770 & -29.86 \\
\hline 4 & 4 & Agassiz Ice Cap 1979 & 80.82 & 72.8 & 1700 & -27.90 & 250.8 & 251.1 & 250.8 & 251.0 & 1770 & -29.00 \\
\hline 5 & 4 & Agassiz Ice Cap 1984 & 80.82 & 72.9 & 1730 & -27.05 & 251.3 & 251.1 & 251.3 & 251.2 & 1770 & -28.82 \\
\hline 6 & 5,6 & Agassiz Ice Cap 1987 & 80.82 & 72.9 & 1730 & -29.25 & 251.3 & 251.1 & 251.3 & 251.2 & 1770 & -28.81 \\
\hline 7 & 7 & Devon Ice Cap (Hole 72) & 75.38 & 82.3 & 1825 & -27.90 & 250.0 & 252.4 & 250.0 & 251.2 & 1500 & -28.05 \\
\hline 8 & 8 & Devon Ice Cap & 75.33 & 82.5 & 1800 & -28.00 & 249.0 & 251.3 & 249.0 & 250,1 & 1500 & -28.85 \\
\hline 9 & 1,2 & Site I & 78.42 & 80.0 & 1390 & -28.10 & 254.0 & 251.4 & 254.0 & 252.7 & 1620 & -27.42 \\
\hline 10 & 1,2 & Site II & 77.55 & 80.3 & 1350 & -26.80 & 256.0 & 252.3 & 256.0 & 254.1 & 1620 & 25.99 \\
\hline 11 & 1,2 & Site III & 76.63 & 78.4 & 660 & -21.10 & 262.0 & 255.8 & 262.0 & 258.9 & 1524 & -22.35 \\
\hline 12 & 1,2 & Laika Island, C: & 75.92 & 79.3 & 490 & -21.10 & 262.0 & 260.1 & 262.0 & 261.0 & 1482 & -20.59 \\
\hline 13 & 9,10 & Axel Heiberg Island $(10, \text { UpIce I })^{\dagger}$ & 79.77 & 90.2 & 1520 & -34.30 & 252.0 & 252.2 & 252.0 & 252.1 & 1645 & -28.25 \\
\hline 14 & 9,10 & Axel Heberg Island (11, Uplce II) & 79.89 & 91.8 & 1920 & -30.00 & 250.8 & 252.3 & 250.8 & 251.6 & 1680 & -28.58 \\
\hline 15 & 11 & Northwest of Tanquary Fd, Elles. Is. & 81.34 & 81.0 & 1800 & -28.70 & 248.6 & 252.8 & 248.6 & 250.7 & 1440 & -30.69 \\
\hline 16 & 12 & Devon Ice Cap $\sim 100 \mathrm{~km}^{*}$ & 75.40 & 83.1 & 1400 & -31.50 & & 251.3 & 251.3 & 251.3 & 1515 & -27.92 \\
\hline 17 & 12 & Devon Ice Cap $\sim 55 \mathrm{~km}^{\ddagger}$ & 75.10 & 82.0 & 1200 & -28.00 & & 252.4 & 252.4 & 252.4 & 1470 & 27.13 \\
\hline 18 & 12 & Devon Ice Cap $\sim 20 \mathrm{~km}^{\ddagger}$ & 74.90 & 81.0 & 400 & -22.00 & - & 255.1 & 255.1 & 255.1 & 1435 & -25.09 \\
\hline 19 & 13 & Ward Hunt Ice Shelf $85-2$ ) & 83.20 & 76.3 & 10 & -32.30 & & 250.7 & 250.7 & 250.7 & 1260 & -32.04 \\
\hline 20 & 13 & Ward Hunt Ice Shelf $(83-4)$ & 83.00 & 73.6 & 10 & -33.30 & - & 251.7 & 251.7 & 251.7 & 1254 & -31.21 \\
\hline 21 & 13 & Milne Ice Shelf (83-7) & 82.70 & 82.0 & 10 & -29.10 & - & 251.7 & 251.7 & 251.7 & 1356 & -30.71 \\
\hline 22 & 13 & Milne Ice Shelf $(84-8)$ & 82.60 & 81.1 & 10 & -31.30 & - & 251.7 & 251.7 & 251.7 & 1356 & -30.67 \\
\hline 23 & 14,15 & Barnes Ice Cap, South Dome (crest) & 69.75 & 72.4 & 890 & -23.00 & 257.0 & - & 257.0 & 257.0 & 900 & -24.00 \\
\hline
\end{tabular}

" 1. Müller and others (1977); 2. Schriber and others (1977); 3. Holdsworth 1984); 4. Fisher and Koerner (1988): 5. Fisher and Koerner (1994): 6. Fisher and others (1995); 7. Paterson and others (1977); 8. Fisher (1979);9. Koerner (1979); 10. Müller (1963);11. West 1972); 12. Koerner and Russell 1979;
13. Jeffries and Krouse (1987); 14. Hooke and Clausen (1982); 15. Holdsworth (1973).

Excluded from final analyses.

† No summer accumulation.

\section{DATABASE}

Data on latitude $(L)$ in degrees north and longitude, surface elevation $(H)$ in $\mathrm{m}$, and mean annual surface temperature $\left(T_{\mathrm{s}}\right.$, in $\left.\mathrm{K}\right)$ normally determined from firn temperature measurements at a depth of $10 \mathrm{~m}$, were stated in the original reports for approximately half of the sites. Missing data were obtained as follows:

(1) $L$ as well as longitude values by interpolation after plotting traverse routes from starting points and marking stated distances along routes.

(2) $H$ values by interpolation from the latest topographic maps available, in some cases shown in the original reports.

(3) $T_{\mathrm{s}}$ values, by extrapolation of shallow firn-temperature measurements at the site (e.g. inferring $10 \mathrm{~m}$ temperature from a temperature observation at a depth of $4 \mathrm{~m}$ in summer), or by interpolation of deep firn-temperature measurements at nearby sites, or by interpolation from isotherm patterns or meteorological station data as compiled in standard reference publications (c.g. Vowinkel and Orvig, 1970).

The methods described above to obtain $T_{\mathrm{s}}$ for sites where temperature data were not reported, could not be applied in the case of seven locations (sites 16-22). To include these in the study, we obtained remotely sensed mean annual surface temperature values $\left(T_{\mathrm{r}}\right)$ in $\mathrm{K}$ by bilinear interpolation from Nimbus-7 Temperature Humidity Infrared Radiometer (THIR) data for 1979 (Comiso, 1994).

The $T_{\mathrm{s}}$ value entered for a location at the crest on the
South Dome of the Barnes Ice Cap (site 23) presented a special case. A firn-temperature measurement at a depth of $20 \mathrm{~m}\left(-8^{\circ} \mathrm{C}\right)$ was considered to be higher than the actual mean annual surface temperature due to melting, percolation, and freezing processes, and in a preceding study the surface temperature was estimated at $-15^{\circ} \mathrm{C}$ (Holdsworth, 1973). This estimate was based on meteorological observations at Dewar Lakes $\left(68.65^{\circ} \mathrm{N}, 74.2^{\circ} \mathrm{W}, 518 \mathrm{~m}\right)$ using a lapse rate of $6.5^{\circ} \mathrm{C} \mathrm{km}^{-1}$ in the extrapolation. We included this site after a first run of the analyses were completed (personal communication from R. LeB. Hooke, August 1996) and did not obtain $T_{\mathrm{r}}$ data for it. Nevertheless, based on $L$, $T_{\mathrm{s}}$, and $T_{\mathrm{r}}$ data from the Penny and Devon Ice Caps (sites 2 and 7) and using lapse rates derived from standard atmospheres for $60^{\circ} \mathrm{N}$ and $75^{\circ} \mathrm{N}$ (Cole and others, 1965) in the interpolation, the mean surface temperature for site 23 was estimated at $-17^{\circ} \mathrm{C}$. Therefore we entered an intermediate $T_{\mathrm{S}}$ value of $257 \mathrm{~K}$ in the database.

Values of mean annual shortest distance to the open ocean $(D)$ in $\mathrm{km}$ were measured between a site location and the position of the $10 \%$ sea-ice-concentration boundary determined from Nimbus-7 Scanning Multi-channel Microwave Radiometer (SMMR) data for 1978-87 (Gloersen and others, 1992). No attempt was made to measure distance to regional polynya during periods of precipitation (e.g. Schriber and others, 1977).

The database thus assembled has inherent shortcomings concerning the two principal variables, $\delta^{18} \mathrm{O}$ and $T_{\mathrm{s}}, T_{\mathrm{r}}$ :

(1) The compiled $\delta^{18} \mathrm{O}$ values are representative of a wide variety of depositional environments (e.g. Fisher and others, 1983) as well as accumulation periods, many not 
overlapping and ranging from fall through spring snow samples to an undetermined number of summer and winter firn layers.

(2) Approximately half of the compiled $T_{\mathrm{s}}$ values were obtained indirectly, as described above, or indirectly by extrapolation or interpolation.

(3) Bilinear interpolation of THIR data does not necessarily produce a more reliable temperature value for a specific site due to the topographic complexity of the region, particularly when the data resolution (about $30 \times$ $30 \mathrm{~km}$ (Comiso, 1994)) in seven of the sites includes both land areas (snow, firn, ice and exposed rock surfaces) and sea areas (snow on sea ice, sea ice and water surfaces).

The undesirable attributes of the $\delta^{18} \mathrm{O}$ and $T_{\mathrm{s}}, T_{\mathrm{r}}$ data mentioned above, as well as the relatively small sample available for this study (varying between $N 14$ and $N 23 ; N$ denotes the number of sites in a set), require that a cautionary note be applied to our findings. The shortcomings presented by the small sample are addressed, in part, using the adjusted coefficient of determination statistic, $R_{a}{ }^{2}$ (correlation coefficient, $R$, squared and modified for sample size (e.g. Tabachnick and Fidell, 1989)). In the following sections, the statistics are significant at the $99.99 \%$ confidence level ( $F$ statistic under the null hypothesis showing a probability of $P \leq 0.0001)$ unless stated otherwise. A confidence level selected for a particular model to determine which variables contribute at that level (or better) to the explanation of variation, is a separate statistic from the $P$-value attained by the model (e.g. Davis and Sampson, 1973).

\section{PRELIMINARY ANALYSES}

Stepwise regression analysis of the data for 16 sites and of the form $\delta^{18} \mathrm{O}=\mathrm{f}\left(L, H, T_{\mathrm{s}}, D\right)$ at the $90 \%$ confidence level showed that only $T_{\mathrm{s}}$ entered the model in the forward mode, or remained in the model in the backward mode (in the case of small datasets it is advisable to run stepwise analyses both forward and backward as the results may be different (e.g. Davis and Sampson, 1973)). Nevertheless, bivariate statistics for $\delta^{18} \mathrm{O}=\mathrm{f}\left(T_{\mathrm{s}}\right)$ showed a moderate correlation (Table 2,

\section{Table 2. Summary of bivariate regression analyses}

\begin{tabular}{|c|c|c|c|c|c|}
\hline Dataset ${ }^{*}$ & Variables & $R$ & $R_{a}{ }^{2}$ & $r m s$ & Pvalue \\
\hline N16 & $\delta^{18} \mathrm{O}=\mathrm{f}\left(T_{s}\right)$ & 0.840 & 0.684 & 2.09 & $<0.0001$ \\
\hline$N 15$ & $\delta^{18} \mathrm{O}=\mathrm{f}\left(T_{\mathrm{s}}\right)$ & 0.931 & 0.856 & 1.24 & $<0.0001$ \\
\hline$N 22$ & $\delta^{18} \mathrm{O}=\mathrm{f}\left(T_{\mathrm{s}}\right)$ & 0.828 & 0.669 & 2.13 & $<0.0001$ \\
\hline$N 22$ & $\delta^{18} \mathrm{O}=\mathrm{f}\left(T_{s}\right)$ & 0.858 & 0.722 & 1.95 & $<0.0001$ \\
\hline$N 14^{+}$ & $T_{\mathrm{r}}=\mathrm{f}\left(T_{\mathrm{s}}\right)$ & 0.810 & 0.628 & 2.31 & 0.0004 \\
\hline$N 15$ & $T_{\mathrm{s}}=\mathrm{f}(H)$ & 0.797 & 0.608 & 3.12 & 0.0004 \\
\hline$N 14^{*}$ & $T_{\mathrm{s}}=\mathrm{f}(H)$ & 0.938 & 0.869 & 1.80 & $<0.0001$ \\
\hline$N 18$ & $T_{\mathrm{a}}=\mathrm{f}(H)$ & 0.688 & 0.441 & 2.88 & 0.0016 \\
\hline$N 22$ & $T_{\mathrm{a}}=\mathrm{f}(\mathrm{H})$ & 0.222 & 0.002 & 3.59 & 0.3216 \\
\hline
\end{tabular}

\footnotetext{
" Difference of N1 between N15 and N16 is the inclusion or exclusion of site 13. Difference of $N 14$ between N18 and N22 is the inclusion or exclusion of sites 19-22 (locations on ice shelves).

$+N 14$ : there is no $T_{\mathrm{r}}$ value for site 23 .

* N14: excluding site 2 .
}

$N 16 ; R$ is $0.840, R_{a}{ }^{2}$ is 0.684 , root mean square residual (rms) is 2.09) (henceforth all bivariate regression analyses are summarized in Table 2 for easy comparison). In Figure 2 the data for site 13 showed the largest departure from the fitted line $(\leq 3 \mathrm{rms}$ ). Its exclusion, to be fully justified, would require a departure $\gg 3 \mathrm{rms}$; however, in a small sample and everything else being equal, data for a single site may greatly modify final results. Therefore, we excluded data from that site $\left(N 15 ; R\right.$ is $0.931, R_{a}{ }^{2}$ is $0.856, \mathrm{rms}$ is 1.24 ):

$$
\delta^{18} \mathrm{O}=-181.305+0.610 T_{\mathrm{s}} .
$$

A comparison of $T_{\mathrm{s}}$ and $T_{\mathrm{r}}$, including sites for which these data are available, showed a moderate correlation (N14; $R$ is $0.810, R_{a}{ }^{2}$ is 0.628 , rms is $2.31, P$ is 0.0004 ), whereas similar comparisons in Antarctica and Greenland result in strong correlations $(R$ values of 0.978 and 0.966 , re-
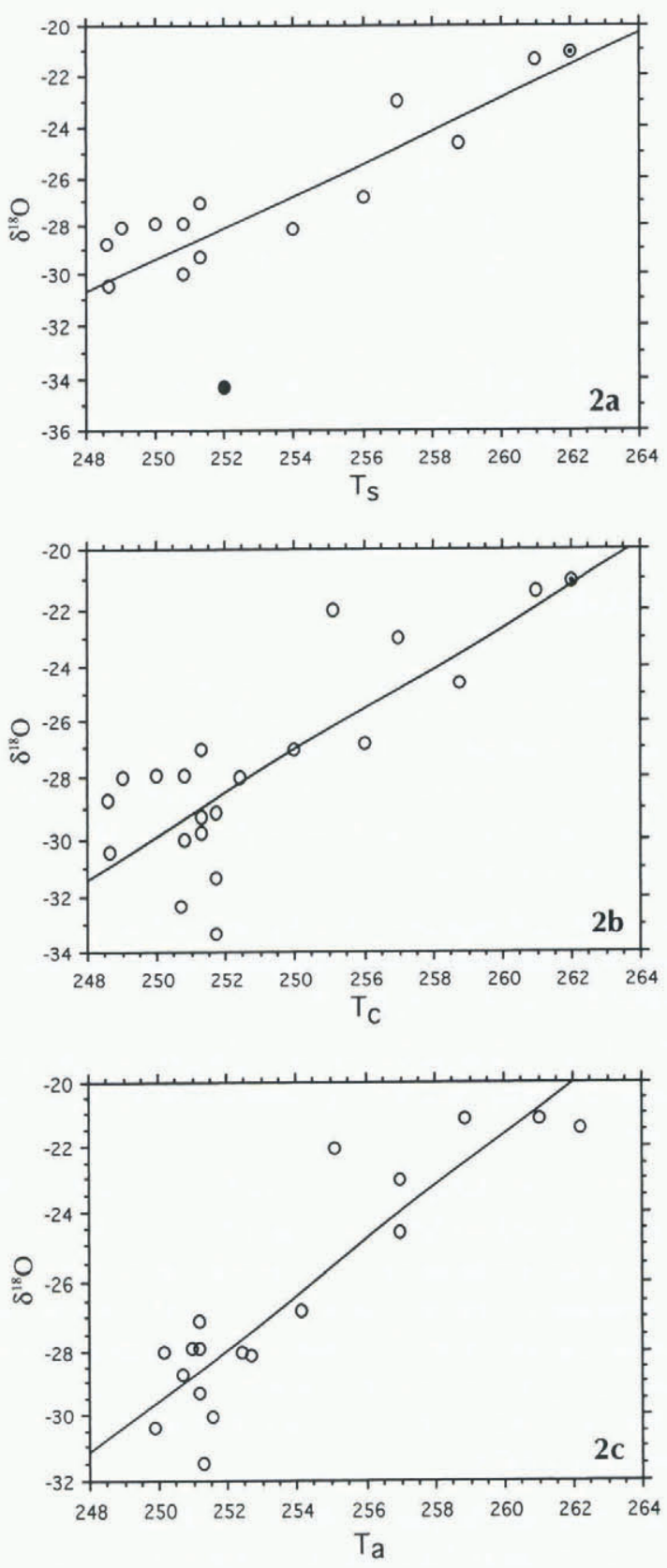

Fig. 2. (a) Scattergram for $N 16, \delta^{18} \mathrm{O}=\mathrm{f}\left(T_{\mathrm{s}}\right)$. The full circle depicts data for site 13; the dot and circle indicate data for two sites. (b) Scattergram for $N 22, \delta^{18} O=\mathrm{f}\left(T_{\mathrm{c}}\right)$. Site 13 is excluded; the dot and circle indicate two sites. (c) Scattergram for $N 22, \delta^{18} O=\mathrm{f}\left(T_{\mathrm{a}}\right)$. Site 13 is excluded. 
spectively (Giovinetto and Zwally, 1997; Zwally and Giovinetto, 1997)). The moderate correlation obtained for a region where topography, surface material, surface slope orientation, and lower tropospheric flow are more complex than on the ice sheets, support the use of $T_{\mathrm{r}}$ values for the remaining seven sites.

There is a slight weakening of the correlation between $\delta^{18} \mathrm{O}$ and temperature relative to that obtained from the $N 15$ set when it is enlarged by the introduction of $T_{\mathrm{r}}$ values for seven sites (Table 1, $T_{c}$; Fig. 2): $N 22, \delta^{18} \mathrm{O}=\mathrm{f}\left(T_{\mathrm{c}}\right), R$ is $0.828, R_{a}{ }^{2}$ is 0.669 , rms is 2.13 . The weakening of the correlation may be explained all or in part by uncertainties in the $T_{\mathrm{s}}$ and $T_{\mathrm{r}}$ data, mentioned above.

In an attempt to reduce uncertainties in the determination of $T_{\mathrm{s}}$ and $T_{\mathrm{r}}$ values, we entered the mean of $T_{\mathrm{s}}$ and $T_{\mathrm{r}}$ where possible, otherwise we entered $T_{\mathrm{r}}$ (Table 1: $T_{\mathrm{n}}$ ). The scattergram of $\delta^{18} \mathrm{O}=\mathrm{f}\left(T_{\mathrm{a}}\right)$ based on the $N 22$ dataset (Fig. 2 ; $R$ is $0.858, R_{a}{ }^{2}$ is 0.722 , rms is 1.95 ):

$$
\delta^{18} \mathrm{O}=-251.415+0.884 T_{\mathrm{a}}
$$

illustrates the principal part of the model eventually selected as best.

It should be noted, however, that all of the following analyses were carried out in the N15,N16 and N22,N23 sets (i.e. including and excluding data from site 13, as well as for datasets using either $T_{\mathrm{s}}$ or $T_{\mathrm{a}}$ ). For brevity, we report only on the basis of the best stepwise model obtained from the $N 22$ set, although the best multiple regression model was obtained from the $N 15$ set (Table 3: largest values of $R$ at 0.951 and $R_{a}{ }^{2}$ at 0.867 , smallest rms is 1.19 ):

$$
\begin{aligned}
\delta^{18} \mathrm{O}= & -112.704+(-0.015 L)+(-2.510 E-3 H) \\
& +0.368 T_{\mathrm{s}}+(-1.493 E-3 D)
\end{aligned}
$$

The multivariate model obtained from the N22 set produces the second largest values of $R$ at 0.915 and $R_{a}{ }^{2}$ at 0.798 , and second smallest $\mathrm{rms}$ is 1.67 ):

$$
\begin{aligned}
\delta^{18} \mathrm{O}= & -200.319+(-0.368 L)+(-9.342-5 H) \\
& +0.774 T_{\mathrm{a}}+3.944 E-3 D
\end{aligned}
$$

Stepwise analysis of the larger dataset should establish which independent variable or variables do not contribute significantly to the explanation of variation.

The descriptive statistics for the $N 22$ set using $T_{\mathrm{a}}$ data (Table 4) show the range of each variable represented in the models. The correlation matrix (Table 5) lists the strong correlation between $\delta^{18} \mathrm{O}$ and $T_{\mathrm{a}}$ already mentioned $(R$ is 0.858 ), and it shows from weak to no correlation between any other pair of variables.

In most cases there are obvious explanations for the lack of correlation. For example, between temperature and ele-

Table 3. Summary of multiple regression analyses ( $\delta^{18} \mathrm{O}$ as the dependent variable)

\begin{tabular}{lccccrr} 
Datasel $^{*}$ & Dependentiariable & $R$ & $R_{a}{ }^{2}$ & $r m s$ & P value \\
\hline \multirow{N}{*}{$N 15$} & $\mathrm{f}\left(L, H, T_{\mathrm{s}}, D\right)$ & 0.951 & 0.867 & 1.19 & $<0.0001$ \\
$N 16$ & $\mathrm{f}\left(L, H, T_{\mathrm{s}}, D\right)$ & 0.857 & 0.637 & 2.25 & 0.0035 \\
$N 22$ & $\mathrm{f}\left(L, H, T_{\mathrm{a}}, D\right)$ & 0.915 & 0.798 & 1.67 & $<0.0001$ \\
$N 23$ & $\mathrm{f}\left(L, H, T_{\mathrm{a}}, D\right)$ & 0.872 & 0.707 & 2.11 & $<0.0001$
\end{tabular}

- Difference of $N 1$ in each pair of sets is the inclusion or exclusion of site 13.
Table 4. Descriptive statistics ( N22)

\begin{tabular}{lrrrrr}
\hline Statistic & $\delta^{18} \mathrm{O}$ & \multicolumn{1}{c}{$L$} & \multicolumn{1}{c}{$H$} & $T_{\mathrm{a}}$ & $D$ \\
& $\% \mathrm{mo}$ & \multicolumn{1}{c}{$\mathrm{N}$} & $\mathrm{m}$ & $\mathrm{K}$ & $\mathrm{km}$ \\
& & & & & \\
\hline Mean & -27.40 & 77.94 & 1138 & 253.4 & 1477 \\
Std dev: & 3.70 & 4.21 & 705 & 3.6 & 299 \\
Minimum & -33.30 & 67.24 & 10 & 249.9 & 480 \\
Maximum & -21.10 & 83.20 & 1940 & 262.2 & 1770 \\
& & & & & \\
\hline
\end{tabular}

Table 5. Correlation matrix ( N22)

\begin{tabular}{lccccr}
\hline & $\delta^{18} \mathrm{O}$ & $L$ & $H$ & $T_{\mathrm{a}}$ & $D$ \\
\hline$\delta^{18} \mathrm{O}$ & 1.000 & -0.611 & -0.014 & 0.858 & 0.195 \\
$L$ & -0.611 & 1.000 & -0.298 & -0.513 & 0.589 \\
$H$ & -0.014 & -0.298 & 1.000 & -0.222 & 0.233 \\
$T_{\mathrm{a}}$ & 0.858 & -0.513 & -0.222 & 1.000 & -0.350 \\
$D$ & 0.195 & 0.589 & 0.233 & -0.350 & 1.000 \\
\hline
\end{tabular}

vation, we obtained a moderate correlation using $T_{\mathrm{s}}(\mathrm{Nl} 15$; $R$ is $0.797, R_{a}{ }^{2}$ is $0.608, \mathrm{rms}$ is $3.12, P$ is 0.0004$)$; the data for site 2 showed a departure $>3 \mathrm{rms}$ from the regression line, and when excluded, the correlation improved significantly (Fig. 3, N14; $R$ is $0.938, R_{a}{ }^{2}$ is $0.869, \mathrm{rms}$ is $1.80, P$ is 0.0001 ). However, using $T_{\mathrm{a}}$ for all sites other than sites 19-22 located on ice shelves, the correlation decays significantly (Fig. 3, $N 18$; $R$ is $0.688, R_{a}{ }^{2}$ is 0.441 , rms is $2.88, P$ is 0.0016 ), and if these sites are included there is no correlation $(N 22 ; R$ is $0.222, P$ is 0.3216 ). The data from the ice shelves would form a cluster outside the elevation scale of Figure 3 not shown, at $H=10 \mathrm{~m}, T_{\mathrm{a}} \sim 251 \mathrm{~K}$ ) that lies $>3 \mathrm{rms}$ from the regression line fitted to the $N 18$ set.

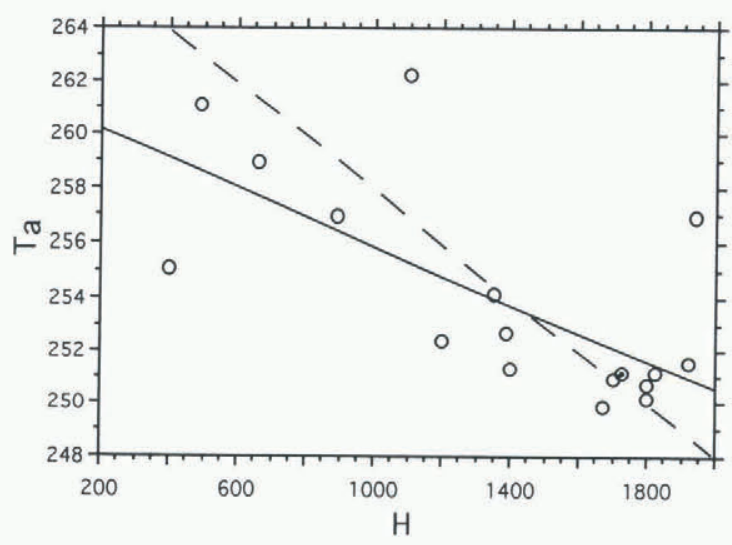

Fig. 3. Scattergram for N18, $T_{\mathrm{a}}=\mathrm{f}(H)$. Sites 13 and $19-22$ are excluded; dot and circle indicale two sites. The dashed line corresponds to $N 14, T_{\mathrm{s}}=\mathrm{f}(H)$; it excludes sites 2 and 13 .

\section{STEPWISE ANALYSIS}

Stepwise analysis of set $N 22$ of the form $\delta^{18} \mathrm{O}=$ $\mathrm{f}\left(L, H, T_{\mathrm{a}}, D\right)$ at the $99.9 \%$ confidence level show that $T_{\mathrm{a}}$ would be the only variable to enter the model in the forward mode (Table 6 : $R$ is $0.858, R_{a}{ }^{2}$ is $0.722, \mathrm{rms}$ is 1.95 ). The same result is obtained in the backward mode, in which the variables are removed in the following order: $H, D, L$. At the 
Table 6. Summary of stepwise regression analyses ( $N 22 ; \delta^{18} O$ as the dependent variable)

\begin{tabular}{|c|c|c|c|c|c|c|c|c|c|c|}
\hline \multirow[t]{2}{*}{ Confidence level } & \multirow{2}{*}{$\begin{array}{c}\text { Step } F / B \\
F / B\end{array}$} & \multicolumn{2}{|c|}{ Independent variables } & \multirow{2}{*}{$\begin{array}{c}R \\
(\text { model })\end{array}$} & \multirow{2}{*}{$\begin{array}{c}R_{a}^{2} \\
\text { (model) }\end{array}$} & \multicolumn{4}{|c|}{ Partial correlations $\left(R_{p}\right)$} & \multirow{2}{*}{$\begin{array}{c}r m s \\
\text { (model) }\end{array}$} \\
\hline & & Inc. & Exc. & & & $L$ & $H$ & $T_{\mathrm{a}}$ & $D$ & \\
\hline$>99 \%$ & $\begin{array}{l}\mathrm{F0} \\
\mathrm{Fl}^{*}\end{array}$ & $\overline{T_{\mathrm{a}}}$ & $L, D, H$ & $\overline{-}$ & $\overline{-}-722$ & $\begin{array}{l}-0.611 \\
0.386\end{array}$ & $\begin{array}{l}0.014 \\
0.408\end{array}$ & 0.858 & $\begin{array}{l}0.195 \\
0.218\end{array}$ & $\begin{array}{l}3.71 \\
1.95\end{array}$ \\
\hline $95 \%$ & $\begin{array}{l}\mathrm{F} 0 \\
\mathrm{~F} 1 \\
\mathrm{~F}^{+}\end{array}$ & $\begin{array}{c}T_{\mathrm{a}} \\
T_{\mathrm{a}}, H\end{array}$ & $L, D$ & $\begin{array}{l}- \\
0.858 \\
0.883\end{array}$ & $\begin{array}{l}- \\
0.722 \\
0.756\end{array}$ & $\begin{array}{l}-0.611 \\
-0.386 \\
-0.233\end{array}$ & $\begin{array}{l}0.014 \\
0.408\end{array}$ & 0.858 & $\begin{array}{r}-0.195 \\
0.218 \\
0.165\end{array}$ & $\begin{array}{l}3.71 \\
1.95 \\
1.83\end{array}$ \\
\hline $95 \%$ & $\begin{array}{l}\mathrm{B} 0 \\
\mathrm{Bl}^{*}\end{array}$ & $\stackrel{\text { all }}{L, T_{\mathrm{a}}, D}$ & $H$ & $\begin{array}{l}0.915 \\
0.915\end{array}$ & $\begin{array}{l}0.798 \\
0.809\end{array}$ & & -0.031 & & & $\begin{array}{l}1.67 \\
1.65\end{array}$ \\
\hline
\end{tabular}

\footnotetext{
* Same results as a run in the backward mode at a confidence level $>99 \%$, step B3: i.e. $T_{\mathrm{a}}$ remains in the model, $H, D$, and $L$ are removed in that order.

* Same results as a run in the forward mode at the $90 \%$ confidence level.

* Best model. Same results as a run in the backward mode at the $90 \%$ confidence level.
}

$95 \%$ confidence level, $T_{\mathrm{a}}$ enters the model first, $H$ second while $L$ and $D$ do not enter $\left(R\right.$ is $0.883, R_{a}{ }^{2}$ is 0.809 , rms is 1.65). Runs at the $90 \%$ confidence level in either the forward or backward mode did not show any changes.

The best model produced using the $N 22$ set in the backward mode at the $95 \%$ confidence level is:

$$
\begin{aligned}
\delta^{18} \mathrm{O}= & -203.501+0.782 T_{\mathrm{a}}+(-0.354 L) \\
& +3.814 E-3 D .
\end{aligned}
$$

This model is similar to that obtained from Greenland data for 46 sites (Zwally and Giovinetto, 1997), also at the 95\% confidence level in the backward mode $\left(R\right.$ is $0.987, R_{a}{ }^{2}$ is 0.973 , rms is 0.53 ):

$$
\begin{aligned}
\delta^{18} \mathrm{O}= & -211.082+0.700 T_{\mathrm{s}}+0.104 L \\
& +(-1.085 E-3 D)
\end{aligned}
$$

where $T_{\mathrm{s}}, L$ and $D$, have the same units and were obtained on the same basis described in this study. It is remarkable that the intercept and temperature coefficient values in Equations (5) and (6) are close, although the Greenland data are, for the most part, representative of central and southern regions, rather than northwestern part.

\section{DISGUSSION AND CONCLUSIONS}

Our findings indicate that despite the relatively small dataset available to study the areal distribution of $\delta^{18} \mathrm{O}$ in northeastern Canada, it is possible to define a multivariate model at an acceptable confidence level. Moreover, the model may be used to produce a contoured pattern based on mean annual surface temperature, latitude and mean annual shortest distance to open ocean, ignoring the effects of surface elevation.

Inversion of Equation (5) produces ratio values $\left(\delta^{18} \mathrm{O}\right)_{\mathrm{i}}$, Table 1) that illustrate local differences between observation and model $\left[\left(\delta^{18} \mathrm{O}\right)-\left(\delta^{18} \mathrm{O}\right)_{\mathrm{i}}\right]$. The difference is largest, as expected, for the location on Axel Heiberg Island that was excluded from most analyses (site 13, $-5.98 \%$ o. For the 22 sites used in the final analysis, the mean difference and std dev. are $-0.11 \pm 1.50 \%$, with a range $-3.60-3.05 \%$ (sites 16 and 18, respectively, both on Devon Island). The difference is smallest for the location on the Penny Ice Cap (site $2,-00.08 \%$ ). This is of interest because, together with the difference for the location on the Barnes Ice Cap (site 23, 1.00\%o), the two sites lie farthest south and away from the cluster to the north, indicating that the model is valid for a large area.

Our data compilation is not suitable to examine the variation of $\delta^{18} \mathrm{O}$ relative to elevation (e.g. over the area of a single ice cap). Nevertheless, it provides the basis to assess why elevation does not contribute to particular stepwise models. As listed in Table 1 , the $\delta^{18} \mathrm{O}$ and $H$ values show no correlation $(N 22 ; R<0.1, P>0.9$ ). Exclusion of the data for ice shelves (sites 19-22) improves the correlation $(N 18 ; R$ is $0.758, P$ is 0.0003$)$. However, the variation over a relatively small area requires using residual $\delta^{18} \mathrm{O}$ values produced in three steps, at each one removing the partial variation explained by $L, D$ and $T_{a}$, respectively. There is no correlation between the $\delta^{18} \mathrm{O}$ residuals produced at the third step and $H$ (N18; $R<0.3, P>0.2$ ).

The best $\delta^{18} \mathrm{O}$ predictive model described for northeastern Canada (Equation (5)) is similar to the best predictive model described for Greenland (Equation (6)), the latter based largely on data from its central and southern regions for which the principal sources of advected moisture are the North Atlantic sector extending from the Labrador Sea to the Norwegian Sea and waters to the south. This suggests that the bulk of the precipitation in Canada sampled by the sites compiled for this study may share moisture advected from that sector.

The description of the sector must be qualified in that it is based on the mean annual position of the $10 \%$ sea-ice concentration boundary. If shortest distance to open ocean is measured using the mean annual position of the $50 \%$ concentration boundary, the description of the sector could be stated as extending from Baffin Bay to the Greenland Sea and waters to the south and east. In any event, the suggestion fits the findings of a detailed study on the origin of Arctic precipitation (Johnsen and others, 1989).

\section{ACKNOWLEDGEMENTS}

The authors gratefully acknowledge contributions of S. Fiegles and R. Poitras in data processing, of R. Koerner in assessing some of the data, and of R. LeB. Hooke for alerting us to include data from the Barnes Ice Cap. We also acknowledge the contributions of the two anonymous reviewers. 


\section{REFERENCES}

Cole, A. E., A. Court and A. J. Kantor. 1965. Model atmospheres. In Valley, S. L., ed. Handbook of geophysics and space environments. New York, etc., McGraw-Hill, 2.1-2.22.

Comiso, J. C. 1994. Surface temperatures in the polar regions from Nimbus 7 temperature humidity infrared radiometer. J. Geophys. Res., 99 C3), $5181-5200$

Davis, J. C. and R. J. Sampson. 1973. Statistics and data analysis in geolog). New York, etc., John Wiley and Sons.

Fisher, D. A. 1979. Comparison of $10^{5}$ years of oxygen isotope and insoluble impurity profiles from the Devon Island and Camp Century ice cores. Quat. Res., 11 (3), 299-305.

Fisher, D. A. and R. M. Koerner. 1988. The effects of wind on $\delta^{18} \mathrm{O}$ and accumulation give an inferred record of seasonal $\delta$ amplitude from the Agassiz Ice Cap, Ellesmere Island, Canada. Ann. Glaciol., 10,34-37.

Fisher, D. A. and R. M. Kocrner. 1994. Signal and noise in four ice-core records from the Agassiz Ice Cap, Ellesmere Island, Canada: details of the last millennium for stable isotopes, melt and solid conductivity. Holocene, 4 2, 113-120.

Fisher, D. A., R. M. Koerner, W. S. B. Paterson, W. Dansgaard, N. Gundestrup and N. Rech. 1983. Effect of wind scouring on climatic records from icecore oxygen-isotope profiles. Nature, 301 (5897), 205-209.

Fisher, D. A., R. M. Koerner and N. Reeh. 1995. Holocene climatic records from Agassiz Ice Cap, Ellesmere Island, N.W.T., Canada. Holocene, 5 1), $19-24$.

Giovinetto, M. B. and H. J. Zwally. 1997. Areal distribution of the oxygenisotope ratio in Antarctica: an assessment based on multivariate models. Ann. Glaciol., 25 (see paper in this volume).

Gloersen, P., W. J. Campbell, D. J. Cavalieri, J. C. Comiso, C. L. Parkinson and H. J. Zwally. 1992. Arctic and Antarctic sea ice, 1978-1987: satellite passivemicroware observations and anabsis. Washington, DC, National Aeronautics and Space Administration. NASA SP-511.

Holdsworth, G. 1973. Correspondence. Barnes Ice Cap and englacial debris in glaciers. J. Glaciol., 12 (64), 147-148.

Holdsworth, G. 1984. Glaciological reconnaissance of an ice core drilling site, Penny Ice Cap, Baffin Island. J. Glaciol., 30 (104), 3-15.

Hooke, R. LeB, and H. B. Clausen. 1982. Wisconsin and Holocene $\delta^{18} \mathrm{O}$ variations, Barnes Ice Cap, Canada. Geol. Soc. Am. Bull., 93 8, 784-789.

Jeffries, M. O. and H. R. Krouse. 1987. Snowfall and oxygen-isotope variations off the north coast of Ellesmere Island, N.W.T., Canada. F. Glaciol. $33114,195-199$.

Johnsen, S. J., W. Dansgaard and J. W. C. White. 1989. The origin of Arctic precipitation under present and glacial conditions. Tellus, 41B 4), 452-468.

Koerner, R. M. 1979. Accumulation, ablation, and oxygen isotope variations on the Queen Elizabeth Islands ice caps, Canada. 7. Glaciol., $2286), 25-41$.

Koerner, R. M. and W. S. B. Paterson. 1974. Analysis of a core through the Meighen Ice Cap, Arctic Canada, and its paleoclimatic implications. Qual. Res., 4(3), 253263.

Koerner, R. M. and R. D. Russell. 1979. $\delta^{18} \mathrm{O}$ variations in snow on the Devon Island ice cap, Northwest Territories, Canada. Can. J. Earth Sci., 16 7), $1419-1427$.

Müller, F. 1963. Englacial temperature measurements. In Müller, F. and 18 others, eds. Jacobsen-Mc Gill Artic Research Expedition 1959-1962; preliminar) report 1961-1962. Montréal, Que., McGill University, 81 89. (Axel Heiberg Island Research Reports.

Müller, F., B. Stauffer and G. Schriber. 1977. Isotope measurements and firn stratigraphy on ice caps surrounding the North Water polynya. International Association of Hydrological Sciences Publication 118 Symposium at Grenoble 1975 - Isolopes and Impurities in Snow and Ice), 188-196.

Paterson, W. S. B. and 7 others. 1977. An oxygen-isotope climatic record fron the Devon Island ice cap. Arctic Canada. Nature, 266 5602 . 508-511.

Schriber, G., B. Stauffer and F. Müller. $1977 .{ }^{18} 0{ }^{16} 0,{ }^{2} \mathrm{H} / 1 \mathrm{H}$ and ${ }^{3} \mathrm{H}$ measurements on precipitation and air moisture samples from the North Water area. International Association of Hydrological Sciences Publication 118 Symposium at Grenoble 1975 - Isotopes and Impurities in Snow and Ice), $182-187$.

Tabachnick, B.G. and L.S. Fidell. 1989. Using multivariate statistics. Second edition. New York, Harper Collins Publishers Inc.

Vowinckel, E. and S. Orvig. 1970. The climate of the north polar basin. In Orvig, S., ed. Climates of the polar regions. New York, Elsevier, 129-252. World Survey of Climatology 14.

West, K. E. 1972. $\mathrm{H}_{2} \mathrm{O}^{18} / \mathrm{H}_{2} \mathrm{O}^{16}$ variations in ice and snow of mountainous regions of Canada. (Ph.D. thesis, University of Alberta.

Zwally, H.J. and M. B. Giovinetto. 1997. Areal distribution of the oxygenisotope ratio in Greenland. Ann. Glaciol., 25 (see paper in this volume). 